Cite as: Hunter, S.C., \& Boyle, J.M.E. (2002). Perceptions of control in the victims of school bullying: The importance of early intervention. Educational Research, 44(3), 323-336

\title{
Perceptions of control in the victims of school bullying: The importance of early intervention.
}

Simon C. Hunter and James M.E. Boyle. Department of Psychology, University of Strathclyde, Glasgow G1 1QE.

Running title: Perceived control in victims of bullying.

Key words: Bullying, victimization, control, appraisal.

Address for correspondence: Correspondence, and requests for reprints or copies of the questionnaire, should be sent to Mr James Boyle, Department of Psychology, University of Strathclyde, Graham Hills Building, 40 George Street, Glasgow G1 1QE,

UK. E-mail: j.boyle@strath.ac.uk

\section{Summary}

Improvements in anti-bullying strategies are likely to depend upon a greater understanding of the psychological processes at work (Sutton et al., 1999b). Transactional theories of coping (e.g. Lazarus \& Folkman, 1984) may be appropriate models to use when examining how the victims of bullying cope with victimization. Research has started to examine the coping strategy aspects of such theories (e.g. Bijttebier \& Vertommen, 1998; Olafsen \& Viemerö, 2000) but has neglected the process of appraisal. The current paper aimed to address this by examining the perceptions of control in the victims of bullying, and how these are influenced by such variables as gender and the severity, persistence, and type of bullying experienced. A self-report questionnaire examining coping responses and perceptions of control regarding the bullying situation was administered to 348 children aged between $9-11$ years. Data from the victims of bullying $(\mathrm{N}=184)$ revealed that girls felt less in control of frequent bullying than infrequent bullying, a trend not evident in boys $(p<.05)$.In addition, a significantly higher proportion of the male victims of bullying felt more in control than female victims $(\mathrm{p}<.01)$. Finally, victims of short-term bullying were significantly more likely to feel in control than were victims of longer-term bullying $(\mathrm{p}<.05)$. The complex relationship between gender, perceptions of control, and the persistence and frequency of bullying has implications for early intervention and for professionals working with the victims of bullying. 


\section{Perceptions of control in the victims of school bullying: The importance of early intervention.}

\section{Summary}

Improvements in anti-bullying strategies are likely to depend upon a greater understanding of the psychological processes at work (Sutton et al., 1999). Transactional theories of coping (e.g. Lazarus \& Folkman, 1984) may be appropriate models to use when examining how the victims of bullying cope with victimization. Research has started to examine the coping strategy aspects of such theories (e.g. Bijttebier \& Vertommen, 1998; Olafsen \& Viemerö, 2000) but has neglected the process of appraisal. The current paper aimed to address this by examining the perceptions of control in the victims of bullying, and how these are influenced by such variables as gender and the severity, persistence, and type of bullying experienced. A self-report questionnaire examining coping responses and perceptions of control regarding the bullying situation was administered to 348 children aged between $9-11$ years. Data from the victims of bullying $(\mathrm{N}=184)$ revealed that girls felt less in control of frequent bullying than infrequent bullying, a trend not evident in boys $(\mathrm{p}<.05)$. In addition, a significantly higher proportion of the male victims of bullying felt more in control than female victims $(\mathrm{p}<.01)$. Finally, victims of short-term bullying were significantly more likely to feel in control than were victims of longer-term bullying $(\mathrm{p}<.05)$. The complex relationship between gender, perceptions of control, and the persistence and frequency of bullying has implications for early intervention and for professionals working with the victims of bullying. 


\section{Introduction}

In the twenty years since Olweus's (1978) seminal work, academic studies of bullying in schools in the main have concentrated on one or two broad approaches: documentation of the problem (e.g. Mellor, 1997; O’Moore \& Kirkham, 2001; Rigby, 1999) or evaluation of intervention and/or prevention programmes (e.g. Besag, 1989; Eslea \& Smith, 1998; Olweus, 1994; Salmivalli, Lappalainen \& Lagerspetz, 1998; Smith \& Sharp, 1994).

While studies of the traits and personality variables of victims allow us to characterise the "typical" victim (Austin \& Joseph, 1996; Lowenstein, 1978; Olweus, 1978; O’Moore \& Kirkham, 2001; Perry, Kusel \& Perry, 1988; Stephenson \& Smith, 1989) they fail to provide us with any insight into how victims try to cope with the problems of bullying. Indeed, the approach leads to a circularity of definition: victims are victims because they are victims (Hepburn, 1997). It fails to take into account the range of behaviour patterns displayed by children who have been victimized (which can include aggressive and provocative behaviours) and indeed the overlap between bullies and victims, such that some children can be bullies in one context but victims in another (Stephenson \& Smith, 1989).

In addition, different types of bullying may themselves influence the way in which victims react. Different researchers have distinguished between direct, indirect and verbal bullying (Whitney \& Smith, 1993), verbal and physical bullying (Boulton \& Underwood, 1992), and relational and overt aggression (Crick \& Grotpeter, 1995), amongst others. The more insidious nature of indirect (relational) bullying, which includes such behaviours as malicious gossiping and social exclusion, and which is more common amongst girls than boys (Bjorkqvist, Lagerspetz, \& Kaukiainen, 1992), may make it less obvious to the child what they can do in response. In addition, indirect bullying can isolate victims from their peers, further reducing the options available for 
tackling the problem. Hawker \& Boulton (2001) report that internalising difficulties (e.g. anxiety and withdrawal) are related to verbal and relational victimization, but are not consistently related to physical bullying.

The bully-victim relationship has been examined using social information-processing theory, where aggression by bullies is viewed as a result of information processing biases or deficits (Crick \& Dodge, 1994). Dodge (1980) found that aggressive boys tended to over-attribute hostile intentions to peers in situations where the intent of the character was somewhat ambiguous. Laird (1997) reports similar results for the victims of bullying, although interestingly, the victims were significantly more likely to attribute hostile intent than either the bullies or uninvolved children in her study. However, the social skills deficit model has not gone unchallenged, with research indicating that bullies actually have superior theory of mind skills compared to other children (Sutton, Smith \& Swettenham, 1999a).

However, when examining how victims of bullying deal with victimization, transactional theories of coping may be the most appropriate models to use. These emphasise coping with stress as a process, rather than a trait (Lazarus \& Folkman, 1984), and have been applied to the investigation of a wide variety of childhood stressors, including both academic and interpersonal problems (Allen \& Heibert, 1991; Band \& Weisz, 1988; Berg, 1989; Broderick, 1998; Compas, 1987; Gomez, 1997; Kliewer, 1991; Miller, Danaher \& Forbes, 1986; Rossman, 1992).

In their influential theory, Lazarus \& Folkman (1984) hold that appraisals (the cognitive interpretations one makes of a particular situation) determine how an individual copes with a stressful situation. They propose two main types of appraisal: primary and secondary. Primary appraisals are the evaluation of the significance of a situation for one's well-being and, should the situation be viewed as potentially harmful, involve a categorisation of the situation as either harm-loss, threat, and/or 
challenge (Lazarus \& Launier, 1978). Secondary appraisals, on the other hand, reflect what a person believes herself able to do in response to a stressor: an evaluation of coping resources and options (Lazarus \& Launier, 1978). Appraisals reflect not only the state of affairs at the beginning of an episode, but also take into account changing personal and environmental variables, this process being referred to as "reappraisal" (Lazarus \& Folkman, 1984).

The appraisal process leads to the deployment of two broad categories of specific coping strategies: problem-focused and emotion-focused (Lazarus \& Folkman, 1984). Problem-focused coping strategies are those which are oriented toward constructively dealing with the problem at hand, while emotion-focused strategies are directed toward the regulation of emotion. In most stressful episodes both will be used to a greater or lesser degree (Folkman \& Lazarus, 1985).

Research supports the notion that a variety of different appraisals are linked with choice of coping strategy (Chang, 1998; Folkman, Lazarus, Dunkel-Schetter, DeLongis \& Gruen, 1986; McCrae, 1984; Ptacek, Smith \& Zanas, 1992). Thus, learning more about the appraisals of bullying victims may shed light on why some victims cope in adaptive and efficacious ways, while others persist with patterns of coping which are maladaptive.

Bijttebier \& Vertommen (1998) examined how children cope with peer arguments, while Olafsen \& Viemerö (2000) looked at how they deal with general school stresses and worries. Both these studies report relationships between bully/victim status and coping strategy use. However, neither examined children's appraisals with regard to the bullying situation, yet it is clear that this is a crucial aspect of coping when applying process theories of stress and coping. 
Folkman (1984) has suggested that perceived degree of situational control serves as a measurement of secondary appraisal, since it is a product of how the individual views his or her ability to deal with the situation, and how well they feel they can implement appropriate strategies. She goes on to note that it is important to take into consideration control over what, since control may be related to the situation itself, emotions arising from the situation, or even consequences of the situation.

Control has been associated with the choice of certain coping strategies in a number of studies. A high degree of control has consistently been associated with greater use of problem-focused coping in adults (Blanchard-Fields \& Irion, 1988; Folkman et al., 1986; Forsythe \& Compas, 1987; Vitaliano, Russo,Carr, Roland, Maiuro \& Becker, 1985). In children and adolescents, control appraisals have also been found to be associated with problem-focused coping (Kliewer, Fearnow \& Walton, 1998) though not all studies have reported finding this effect (Halstead, Johnson \& Cunningham, 1993). In addition, Bowker, Bukowski, Hymel \& Sippola (2000) found in their study of $7^{\text {th }}$ grade students (i.e. approximately 13 years old) that the pattern between high control and greater use of problem focused coping was only true for girls - in boys, the opposite pattern was discovered.

However, whether there are gender differences in the perceptions of control held by children and adolescents is unclear. Causey \& Dubow (1992) reported that amongst 9 to 13 year olds, girls reported significantly greater control than boys in both academic and peer-conflict situations. However, Halstead et al. (1993) and Bowker et al. (2000) both failed to find straightforward gender differences in perceived control.

The findings from such studies, applied to the bully/victim situation, support three hypotheses regarding the relationship between gender and persistence of bullying upon perceptions of control: 
1. girls will report higher perceived control of the bully-victim situation than will boys, since bullying is a peer-conflict situation;

2. victims of indirect and verbal bullying will also report lower perceived control of the bully-victim situation as, by their very nature, these types of bullying rely on social manipulation rather than direct confrontation (Sutton, Smith and Swettenham, 1999b);

3. finally, data reported by Jerusalem \& Schwarzer (1992) suggest that repeated failure in a task induces low perceived control. Assuming that victims of longer term bullying have engaged unsuccessfully in various attempts to stop bullying, it is further predicted that longer-term victims will have lower perceived control over bullying than shorter-term victims.

\section{Method}

\section{Participants}

The participants were 348 children (47\% male and 53\% female) aged between $9-11$ years from Primary Five and Primary Six classes in four large primary schools in inner-city Glasgow. Four children were excluded from the analysis due to incomplete data regarding gender. Two of the four schools were nondenominational, while two were denominational.

\section{Questionnaire design}

A questionnaire was designed to collect general bullying information (prevalence, location, frequency, duration, etc.) as well as information relating specifically to perceptions of control. Victims completed 32 items, while non-victims completed only 25 items. Checklists were used to determine type of victimization (called names, threatened etc.), location of bullying, and characteristics of bullies (older, younger, individual, group etc). A definition was presented at the beginning of the questionnaire: 
"When we talk about bullying, we mean anything which one or more people do to another person to hurt or upset them. Also, bullying is something which does not happen once - it happens again and again”.

Some alternative definitions make the explicit requirement that bullying should involve an imbalance of power between the perpetrator and the victim, to distinguish it from aggressive behaviour in general (Whitney and Smith, 1983; Sutton et al., 1999b). However, the phenomenological nature of transactional coping theory emphasises the importance of how the individual views his or her situation rather than how it might objectively be classified. The broader definition used here allows the children's perceptions of bullying to be captured and is also consistent with the definitions used in current guidelines for schools and pupils produced by the Department for Education and Employment in England and Wales (DfEE, 1995) and the Scottish Executive Education Department (SOEID, 1995; SEED, 1999), which emphasise only that bullying can be physical or psychological harm, and that the behaviour is repeated time and again rather than occurring only once.

Following the above bullying definition, students were asked "Have you been bullied in any of these ways since the summer?" and tick-boxes were then presented beside eight separate bullying behaviours ("Called names", "Threatened", "Forced to give money to bully(s)", "Left out of things", "Your things damaged", "Rumours spread about you", "Being hit", and "Forced to do things"). Those children reporting bullying were then asked "How often did it happen?" with possible responses "Every day", "Every week" or "Most weeks".

A checklist of potential coping strategies was used to examine how victims dealt with bullying both when it began and currently. These were based on strategies reported in previous studies (McLean, 1994; Whitney \& Smith, 1993). Duration of victimization was measured by asking children "over how long a period" the bullying had been 
going on, and forced choice responses were "1 - 4 weeks", "1 - 3 months", "3 - 6 months", and "more than 6 months". Short-term victimization was operationally defined as one to four weeks, longer-term as more than four weeks.

Children uninvolved in bully/victim problems were asked to complete a similar checklist examining how they felt children should deal with bullying. Perceptions of situational control were operationally defined as the child's beliefs regarding their control over the bullying episode, and were assessed by asking children to answer "yes" or "no" to the question "Did you feel that you could stop the bullying?" Previous research, also based on the Folkman \& Lazarus model, examining appraisals in adolescents (Halstead, et al., 1993) and adults (Forsythe \& Compas, 1987; Vitaliano, DeWolfe, Maiuro, Russo \& Katon, 1990) has found single item, dichotomous measures of control to be both reliable and valid.

The questionnaire was piloted on a focus group of three appropriate age children and one teacher experienced in dealing with the age group in question and the wording, presentation and layout were modified in the light of the feedback received.

\section{Procedure}

The questionnaires were administered to whole classes by the class teachers. Teachers were asked to read aloud the definition at the start of the questionnaire and then to help children in any way they required. Completion of the questionnaire took approximately 15 minutes.

\section{Results}

Prevalence rates of bullying broken down by school and for the sample as a whole are presented in Table 1. One hundred and eighty-four children (53\% of the total sample) reported being the victims of bullying. There were no significant differences in the 
prevalence of bullying between the four schools $\left(\chi^{2}(9)=11.16\right.$, n.s.). Sixty-three percent of bullied children reported that the bullying was a short-term problem, while the remaining $37 \%$ reported that the bullying was a longer-term problem.

\section{TABLE 1 about here}

The prevalence of specific types of persistent bullying is shown in Table 2. Name calling was the commonest form of persistent bullying and accounted for $44 \%$ of all reported incidents. Analysis of the effects of gender upon type of bullying (verbal versus direct versus indirect) failed to reach statistical significance $\left(\chi^{2}(2)=4.46\right.$, n.s. $)$.

\section{TABLE 2 about here}

Data for 177 victimized children $(7$ children failed to report one or other of the variables) (52\% male and $48 \%$ female) were entered into a hierarchical log-linear analysis ${ }^{1}$ with gender, persistence of bullying (short-term versus longer-term), frequency of bullying (every day, every week, most weeks) and perceptions of control (in control versus not in control) as dichotomous independent variables (see Table 3 for contingency table). The final model displayed the following significant associations: gender $\mathrm{x}$ frequency $\mathrm{x}$ control (likelihood ratio $\left.\chi^{2}(2)=6.46, \mathrm{p}<0.05\right)$, duration $\mathrm{x}$ control (likelihood ratio $\chi^{2}(1)=14.77, \mathrm{p}<0.01$ ) and duration $\mathrm{x}$ frequency (likelihood ratio $\left.\chi^{2}(2)=9.20, p<0.01\right)$. The model had a good fit between observed and expected frequencies (likelihood ratio $\chi^{2}(8)=7.51$, n.s., see Table 4 ).

TABLE 3 about here

TABLE 4 about here 
The significant gender $\mathrm{x}$ frequency $\mathrm{x}$ control interaction was further investigated by means of chi-square analyses of the frequency $\mathrm{x}$ control interaction for males and females. The results revealed that significantly more female victims reported feeling no control of the bully-victim situation when bullying occurred daily $(76 \%)$ or weekly (88\%) than would be expected by chance, and significantly fewer female victims (56\%) reported no control when the bullying occurred "most weeks" $\left(\chi^{2}(2)=6.51, p<0.05\right)$. No such frequency effect existed for the male sample $\left(\chi^{2}(2)=1.61\right.$, n.s. $)$.

With regard to the duration $\mathrm{x}$ control interaction, significantly more of the victims of short-term bullying felt more in control than victims of longer-term bullying (55\% versus $26 \%$ ). The duration $\mathrm{x}$ frequency interaction indicated than the longer bullying continued, the more frequent it became.

Complete data across gender, type of bullying and perceptions of control were available for 150 victimized children (49\% male and 51\% female): 34 children failed to report on one or other of these variables. The data, shown in Table 5, were entered into a hierarchical log-linear analysis with gender, type of bullying (verbal, direct, indirect) and perceptions of control (in control versus not in control) as dichotomous independent variables ${ }^{2}$. The final model included only one significant association, gender $\mathrm{x}$ control (likelihood ratio $\left.\chi^{2}(1)=9.97, \mathrm{p}<0.01\right)$. The model had a good fit between observed and expected frequencies (likelihood ratio $\chi^{2}(6)=9.96$, n.s., see Table 6).

TABLE 5 about here

TABLE 6 about here 
Significantly more of the male victims reported feeling in control of the bully-victim situation than female victims (53\% versus $29 \%$ ) and reported that they would be able to stop the bullying.

Finally, the perceptions of control of children who reported being bullied by older children (i.e. where there was an imbalance of power, corresponding more closely to Whitney \& Smith's (1993) definition of bullying) were compared with those of children who reported being bullied by pupils of the same age or younger. The results revealed no significant differences in degree of perceived control in either the male $\left(\chi^{2}\right.$ $(1)=0.61$, n.s., $\mathrm{N}=87)$ or the female $\left(\chi^{2}(1)=0.32\right.$, n.s., $\left.\mathrm{N}=73\right)$ victims.

\section{Discussion}

The results of the study reveal interesting interactions between gender, frequency of bullying, and perceptions of control, and between persistence of bullying and perceptions of control. Although there was no relationship between gender and type of persistent bullying, when girls encounter frequent bullying, within the age range examined, they have lower perceptions of control, a pattern which is not evident for boys. In addition, perceptions of control are greatest when bullying first starts, but are reduced by its persistence.

These differences in control perceptions may have implications for how victims of bullying respond to their predicament, and hence for intervention. Teaching a child problem-focused coping strategies when they have appraised a situation as one which is out of their control may not have a major impact upon coping unless their perception of the situation is also changed. Once a situation is viewed as one which the child feels

they have the ability to alter, then they might use the constructive strategies they have been taught: otherwise, they may be more likely to use strategies that are directed towards emotion-regulation (see McCrae, 1984, Parkes, 1984, and Smith \& Ellsworth, 
1985, for supporting evidence from adults and Gomez, 1997, for evidence from adolescents).

In the present study, short-term victimization was operationalised as "1 to 4 weeks", and longer-term as more than 4 weeks. The results reported thus highlight the importance of early intervention in the bully-victim relationship. A failure to intervene early may lead to victims developing appraisals which discourage pro-active behaviour, leading to an increase in the likelihood of extended victimization (Egan \& Perry, 1998). Interestingly, Sharp, Thompson \& Arora (2000) report that school anti-bullying initiatives influence "mild" victimization, yet leave the incidence of long-term bullying almost unchanged. This may indicate that the appraisals children hold regarding their ability to tackle peer aggression, in its early stages, are compatible with the intervention work currently carried out. However, professionals tackling persistent bullying may need to either encourage coping strategy use which is more suited to long-term victims' appraisals, or ensure that children's feelings and appraisals with respect to bullying are changed at the same time as new coping strategies are taught.

It could be argued that there is a circularity in saying that as bullying persists, so too do perceptions of control, since it appears self-evident that a child who is in a long-term bullying situation cannot control it. However, closer examination of the data suggests the situation is not as clear cut as this since $45 \%$ of children in the short-term victim group reported that they did not feel in control of the situation. Conversely, over a quarter (26\%) of those of those who were subjected to long-term bullying still felt they did have control. The existence of these groups tell us two things: firstly, a large proportion of children between 9 and 11 years old feel that they cannot exercise personal control over bullying situations when they have just started, possibly laying the foundations for prolonged victimization. Secondly, children who have been bullied for extended periods of time (over four weeks) do not simply succumb to bullying, but often retain a belief in their ability to change the situation to their advantage. 
Although it seems irrational that a child who is being bullied would not stop the bullying if they could, there may be good reasons why children do not, in fact, stop bullying: telling a teacher may be an effective way to stop bullying, but it may also bring costs (e.g. stigmatisation as a "tell-tale") which, to the victim, outweigh the benefits. Furthermore, a study of adult, female victims of partner violence suggests that perceptions of control themselves serve a protective function as they are negatively correlated with both depression and anxiety (Pape \& Arias, 1995), implying that people may work hard to retain a feeling of control even when there may objectively be little possibility of executing it. Kerig's (1998) study examining the effects of interparental conflict on children's adjustment also found that high personal control worked as a buffer against the development of externalising problems in boys. However, Kerig also reports that high control in girls was associated with increased risk of developing internalising problems in girls. It may thus be beneficial for future research to investigate the perceptions of control in long-term victims since clarification of what these are, and why they are not translated into concrete action, may inform intervention studies.

With respect to gender differences, boys reported greater perceived control over bullying than did girls, a finding which was unexpected given the findings of Causey $\&$ Dubow (1992). This discrepancy may be attributable to the fact that Causey \& Dubow asked children about perceived control when they have "an argument or a fight with a friend" while the current study asked about more serious interpersonal conflict. Hence, girls may indeed feel more able to resolve and deal with conflicts with friends, but when such problems are with strangers, or when they become more drawn-out, they may feel less confident in their ability to resolve the situation. This possibility is backed up by the second gender difference reported which revealed that boys' perceptions of control are not influenced by the frequency of bullying yet girls feel less in control of daily and weekly bullying compared to bullying occurring "most weeks". 
There may also be a 'social desirability' bias operating, with boys trying to appear "macho" by over-reporting control of the bullying situation. However, the extent to which this was present in the current sample is unclear, and reflects a weakness inherent in survey based research. An alternative explanation, that boys and girls were experiencing different types of bullying, was ruled out as no significant difference in the type of bullying experienced was discovered.

Furthermore, perceived control was not even related to the experience of different types of bullying. This suggests that children's reactions to direct, indirect, and verbal bullying are not related to how much control they have over them. Differences in reported coping strategy use according to type of bullying (Bijttebier \& Vertommen, 1998) may thus be a function of other, more salient, differences between these bullying types. The distinction Lazarus \& Folkman (1984) draw between appraisals of challenge and threat may be of relevance here, and future research should examine whether different types of bullying are perceived to be more threatening or challenging than others, as such perceptions represent more potential methods of intervention for professionals.

The final finding, that children who reported being bullied by an older child felt no less in control than children bullied by same-age peers, suggests that imbalance of power (at least using bullying by an older child as a crude measure of imbalance of power) does not influence perceptions of control.

The reliance on self-report measures, which tend to result in higher prevalence rates compared with other measures of bullying (Boyle, 1996), is a limitation of the present study. Self-report data was necessary to investigate perceptions of control, but in future studies should be cross-validated with, for example, peer- or teacher-nomination data, or observational data. 
The levels of victimization reported represent a higher prevalence rate for this age-group than that reported by other researchers in the UK (e.g. Boulton \& Underwood, 1992; Whitney \& Smith, 1993), but may reflect a general attitude toward a "telling ethos" fostered by school initiatives in Scotland designed to counter bullying (McDonald, 1999). In addition, the questionnaire in the present study was designed to maximise the reporting of possible bullying incidents by the use of a broad definition of bullying.

The use of cross-sectional data is a further limitation. While the data reveals that duration of bullying exerts an influence over perceptions of control, it may be that longer-term victims represent a group who, rather than developing low perceptions of control, had low perceptions of control from the beginning of the bullying. Longitudinal data is required to examine this issue.

In conclusion, it is likely that future advances in tackling bullying may rest on developing our understanding of the psychological variables implicated in bully-victim problems (Sutton et al., 1999b). Transactional models such as Lazarus \& Folkman's (1984) provide a useful account of the complex relationship between gender, persistence of bullying, frequency of bullying, and victims' perceptions of control and have implications for the timing and nature of intervention. 


\section{References}

ALLEN, S. and HIEBERT, B. (1991). 'Stress and coping in adolescents', Canadian Journal of Counselling, 25, 19-32.

AUSTIN, S. and JOSEPH, S. (1996). 'Assessment of bully/victim problems in eight to eleven year olds', British Journal of Educational Psychology, 66, 447-456.

BAND, E. and WEISZ, J.R. (1988). 'How to feel better when it feels bad: Children's perspectives on coping with everyday stress', Developmental Psychology, 24, 247-253.

BERG, C.A. (1989). 'Knowledge of strategies for dealing with everyday problems from childhood through adolescence', Developmental Psychology, 25, 607-618.

BESAG, V.E. (1989). Bullies and Victims in Schools. Buckingham: Open University Press.

BIJTTEBIER, P. and VERTOMMEN, H. (1998). 'Coping with peer arguments in school-age children with bully/victim problems', British Journal of Educational Psychology, 68, 387-394.

BJORKVIST, K., LAGERSPETZ, K.M.J. and KAUKIAINEN, A. (1992). 'Do girls manipulate and boys fight? Developmental trends in regard to direct and indirect aggression', Aggressive Behavior, 18, 117-127.

BLANCHARD-FIELDS, F. and IRION, J.C. (1988). 'Coping strategies from the perspective of two developmental markers: Age and social reasoning', Journal of Genetic Psychology, 149, 141-151. 
BOULTON, M.J and UNDERWOOD, K. (1992). 'Bully/victim problems among middle school children', British Journal of Educational Psychology, 62, 73-87.

BOWKER, A., BUKOWSKI, W.M., HYMEL, S. and SIPPOLA, L.K. (2000). 'Coping with daily hassles in the peer group during early adolescence: Variations as a function of peer experience', Journal of Research on Adolescence, 10, 211-243.

BOYLE, J. (1996). 'Bullying as a social problem in schools.' In B GILLHAM, JA THOMSON, editors. Child safety: Problem and prevention from preschool to adolescence. London. Routledge.

BRODERICK, P.C. (1998). 'Early adolescent gender differences in the use of ruminative and distracting coping strategies', Journal of Early Adolescence, 18, 173-191.

CAUSEY, D.L. and DUBOW, E.F. (1992). 'Development of a self-report coping measure for elementary school children', Journal of Clinical Child Psychology, 21, 47-59.

CHANG, E.C. (1998). 'Dispositional optimism and primary and secondary appraisal of a stressor: Controlling for confounding influences and relations to coping and psychological and physical adjustment', Journal of Personality and Social Psychology, 74, 1109-1120.

COMPAS, B.E. (1987). 'Coping with stress during childhood and adolescence', Psychological Bulletin, 101, 393-402. 
CRICK, N.R. and DODGE, K.A. (1994). 'A review and reformulation of social information-processing mechanisms in children's social adjustment', Psychological Bulletin, 115, 74-101.

CRICK, N.R. and GROTPETER, J.K. (1995). 'Relational aggression, gender and social-psychological adjustment', Child Development, 66, 710-722.

DEPARTMENT FOR EDUCATION AND EMPLOYMENT. (1995). 'Protecting children from abuse: the role of the education service', Circular number 10/95. London: HMSO.

DODGE, K.A. (1980). 'Social cognition and children's aggressive behaviour', Child Development, 51, 162-170.

EGAN, S.K. and PERRY, D.G. (1998). 'Does low self-regard invite victimization?', Developmental Psychology, 34, 299-309.

ESLEA, M. and SMITH, P.K. (1998). 'The long-term effectiveness of anti-bullying work in Primary schools', Educational Research, 40, 203-218.

FOLKMAN, S. (1984). 'Personal control and stress and coping processes: A theoretical analysis', Journal of Personality and Social Psychology, 46, 839-852.

FOLKMAN, S. and LAZARUS, R.S. (1985). 'If it changes it must be a process: Study of emotion and coping during three stages of a college examination', Journal of Personality and Social Psychology, 48, 150-170. 
FOLKMAN, S., LAZARUS, R.S., DUNKEL-SCHETTER, C., DELONGIS, A. and GRUEN, R.J. (1986). 'Dynamics of a stressful encounter: cognitive appraisal, coping, and encounter outcomes', Journal of Personality and Social Psychology, 50, 992-1003.

FORSYTHE, C.J. and COMPAS, B.E. (1987). 'Interaction of cognitive appraisals of stressful events and coping: Testing the goodness of fit hypothesis', Cognitive Therapy and Research, 11, 473-485.

GOMEZ, R. (1997). 'Locus of control and Type A Behaviour pattern as predictors of coping styles among adolescents', Personality and Individual Differences, 23, 391-398.

HALSTEAD, M., JOHNSON, S.B. and CUNNINGHAM, W. (1993). 'Measuring coping in adolescents: An application of the Ways of Coping Checklist', Journal of Clinical Child Psychology, 22, 337-344.

HAWKER, D.S.J. and BOULTON, M.J. (2001). 'Subtypes of peer harassment and their correlates: A Social Dominance perspective.' In J. JUVONEN and S. GRAHAM, editors. Peer harassment in school. New York: Guilford.

HEPBURN, A. (1997). 'Teachers and secondary school bullying: A post-modern discourse analysis', Discourse and Society, 8, 27-48.

JERUSALEM, M. and SCHWARZER R. (1992). 'Self-efficacy as a resource factor in stress appraisal processes.' In R. SCHWARZER, editor. Self-Efficacy: Thought Control of Action. USA: Taylor \& Francis.

KERIG, P.K. (1998). 'Moderators and mediators of the effects of interparental conflict on children's adjustment', Journal of Abnormal Child Psychology, 26, 199-212. 
KLIEWER, W. (1991). 'Coping in middle childhood: Relations to competence, Type A behaviour, monitoring, blunting, and locus of control', Developmental Psychology, 25, $607-618$

KLIEWER, W., FEARNOW, M.D. and WALTON, M.N. (1998). 'Dispositional, environmental, and context-specific predictions of children's threat perceptions in everyday stressful situations', Journal of Youth and Adolescence, 27, 83-100.

LAIRD, J. (1997). 'The perception of bullying behaviour by primary school children: An investigation of the role of intentionality', Unpublished Batchelor of Arts (Honours) thesis, University of Strathclyde, Glasgow.

LAZARUS, R.S. and FOLKMAN, S. (1984). Stress, Appraisal, and Coping. New York: Springer Publishing Company.

LAZARUS, R.S. and LAUNIER, R. (1978). 'Stress-related transactions between person and environment.' In L.A. PERVIN and M. LEWIS, editors. Perspectives in Interactional Psychology. London: Plenum Press.

LOWENSTEIN, L.F. (1978). 'Who is the bully?', Bulletin of the British Psychological Society, 31, 147-149.

MCCRAE, R.R. (1984). 'Situational determinants of coping responses: Loss, threat, and Challenge', Journal of Personality and Social Psychology, 46, 919-928.

MCDONALD, M. (1999, June). 'FAB - Friends Against Bullying', Seminar presentation at the Anti-Bullying Network Inaugural Conference, Edinburgh. 
MCLEAN, A.V. (1994). 'Bullying survey in Strathclyde Region', Glasgow North East Psychological Service, Strathclyde Regional Council.

MELLOR, A. (1997). 'Bullying: The Scottish experience', The Irish Journal of Psychology, 18, 248-257.

MILLER, P.M., DANAHER, D.L. and FORBES, D. (1986). 'Sex-related strategies for coping with interpersonal conflict in children aged five and seven', Developmental Psychology, 22, 543-548.

OLAFSEN, R.N. and VIEMERÖ, V. (2000). 'Bully/victim problems and coping with stress in school among 10- to 12-year-old pupils in Aland, Finland', Aggressive Behavior, 26, 57-65.

OLWEUS, D. (1978). Aggression in the Schools. Washington, D.C.: Hemisphere.

OLWEUS, D. (1994). 'Annotation: Bullying at school: Basic facts and effects of a school based intervention program', Journal of Child Psychology and Psychiatry, 35, 1171-1190.

O'MOORE, M. and KIRKHAM, C. (2001). 'Self-esteem and its relationship to bullying behaviour', Aggressive Behavior, 27, 269-283.

PAPE, K.T. and ARIAS, I. (1995). 'Control, coping, and victimization in dating relationships', Violence and Victims, 10, 43-54. 
PARKES, K. (1984). 'Locus of control, cognitive appraisal, and coping in stressful episodes', Journal of Personality and Social Psychology, 46, 655-186.

PERRY, D.G., KUSEL, S.J. and PERRY, L.C. (1988). 'Victims of peer aggression', Developmental Psychology, 24, 807-814.

PTACEK, J.T., SMITH, R.E. and ZANAS, J. (1992). 'Gender, appraisal, and coping: A longitudinal analysis', Journal of Personality, 60, 747-770.

RIGBY, K. (1999). 'Peer victimization at school and the health of Secondary school students', British Journal of Educational Psychology, 69, 95-104.

ROSSMAN, B.B.R. (1992). 'School-age children's perceptions of coping with distress: Strategies for emotion regulation and the moderation of adjustment', Journal of Child Psychiatry, 33, 1373-1397.

SALMIVALLI, C., LAPPALAINEN. M. and LAGERSPETZ, K.M.J. (1998). 'Stability and change of behaviour in connection with bullying in schools: A two-year follow-up', Aggressive Behavior, 24, 205-218.

SCOTTISH EXECUTIVE EDUCATION DEPARTMENT (1999). Let's Stop Bullying: Advice for Young People. Edinburgh: HMSO.

SHARP, S., THOMPSON, D. and ARORA, T. (2000). 'How long before it hurts? An investigation into long-term bullying', School Psychology International, 21, 37-46.

SMITH, C.A. and ELLSWORTH, P.C. (1985). 'Patterns of cognitive appraisal in emotion', Journal of Personality and Social Psychology, 48, 813-838. 
SMITH, P.K. and SHARP, S. (1994). School Bullying. Insights and Perspectives. London: Routledge.

STEPHENSON, P. and SMITH, D. (1989). 'Bullying in the Junior school.' In D.P. TATTUM and D.A. LANE, editors. Bullying in Schools. Stoke-on-Trent. Trentham Books.

SUTTON, J., SMITH, P.K. and SWETTENHAM, J. (1999a). 'Social cognition and bullying: Social inadequacy or skilled manipulation?', British Journal of Developmental Psychology, 17, 435-451.

SUTTON, J., SMITH, P.K. and SWETTENHAM, J. (1999b). 'Bullying and "theory of mind": A critique of the "social skills deficit" view of anti-social behaviour', Social Development, 8, 117-127.

TABACHNICK, B.G. and FIDELL, L.S. (1996). Using Multivariate Statistics. USA: HarperCollins.

VITALIANO, P.P., DEWOLFE, D.J., MAINRO, R.D., RUSSO, J. and KATON, W. (1990). 'Appraised Changeability of a Stressor as a Modifier of the Relationship Between Coping and Depression: A Test of the Hypothesis of Fit', Journal of Personality and Social Psychology, 59, 582-592.

VITALIANO, P.P., RUSSO, J., CARR, J.E., MAIURO, R.D. and BECKER, J. (1985). 'The Ways of Coping Checklist: Revision and psychometric properties', Multivariate Behavioral Research, 20, 3-26. 
WHITNEY, I. and SMITH, P.K. (1993). 'A survey of the nature and extent of bullying in Junior/ Middle and Secondary schools', Educational Research, 35, 3-25. 
FOOTNOTE 1 - This is a technique for examining how a discrete dependent variable (in this case, control) is influenced by one or more discrete independent variables (in this case, gender, persistence of bullying and frequency of bullying) and their associations.

FOOTNOTE 2 - Note that type of bullying was not included in the previous log-linear analysis as this would have violated Tabachnick \& Fidell's (1996) recommendation that there be at least 5 times as many subjects as cells. 
TABLE 1 Prevalence of bullying behaviours shown by school

\begin{tabular}{|lccccc|}
\hline Frequency: & $\begin{array}{c}\text { School A } \\
(N=74)\end{array}$ & $\begin{array}{c}\text { School B } \\
(N=117)\end{array}$ & $\begin{array}{c}\text { School C } \\
(N=48)\end{array}$ & $\begin{array}{c}\text { School D } \\
(N=109)\end{array}$ & $\begin{array}{c}\text { Total } \\
(N=348)\end{array}$ \\
Everyday & $12 \%$ & $19 \%$ & $13 \%$ & $17 \%$ & $16 \%$ \\
Everyweek & $11 \%$ & $11 \%$ & $6 \%$ & $12 \%$ & $11 \%$ \\
Most Weeks & $22 \%$ & $21 \%$ & $33 \%$ & $31 \%$ & $26 \%$ \\
No Response & $1 \%$ & $3 \%$ & $2 \%$ & $6 \%$ & $3 \%$ \\
Not Bullied & $54 \%$ & $46 \%$ & $46 \%$ & $33 \%$ & $44 \%$ \\
\hline
\end{tabular}


TABLE 2 Prevalence of specific types of persistent bullying

\begin{tabular}{|c|c|c|c|c|c|c|c|c|c|c|c|}
\hline \multirow{3}{*}{ Gender } & \multicolumn{11}{|c|}{ Frequencies of Types of Persistent Bullying } \\
\hline & \multicolumn{2}{|c|}{ Verbal } & \multicolumn{4}{|c|}{ Direct } & \multicolumn{2}{|c|}{ Indirect } & \multirow{2}{*}{ Other } & \multirow{2}{*}{$\begin{array}{c}\text { Missing } \\
\text { Data }\end{array}$} & \multirow{2}{*}{ Tota } \\
\hline & $\begin{array}{c}\text { Name-Cal } \\
\quad \text { ling } \\
\end{array}$ & Threats & Extortion & Coercion & Damage & Violence & Rumours & Exclusion & & & \\
\hline Male & 45 & 1 & 1 & 3 & 1 & 13 & 4 & 8 & 9 & 10 & 95 \\
\hline Female & 36 & 1 & 4 & 4 & 2 & 7 & 5 & 18 & 7 & 5 & 89 \\
\hline Total & 81 & 2 & 5 & 7 & 3 & 20 & 9 & 26 & 16 & 15 & 184 \\
\hline
\end{tabular}


TABLE 3 Contingency table for gender, duration of bullying, frequency of bullying and perceived control

\begin{tabular}{|c|c|c|c|c|}
\hline Gender & Duration & Frequency & Control & No Control \\
\hline \multirow{6}{*}{ Male } & \multirow{3}{*}{ Short-Term } & Everyday & 10 & 4 \\
\hline & & Every week & 8 & 3 \\
\hline & & Most weeks & 22 & 11 \\
\hline & \multirow{3}{*}{ Longer-Term } & Everyday & 4 & 8 \\
\hline & & Every week & 6 & 3 \\
\hline & & Most weeks & 3 & 10 \\
\hline \multirow{6}{*}{ Female } & \multirow{3}{*}{ Short-Term } & Everyday & 6 & 8 \\
\hline & & Every week & 2 & 7 \\
\hline & & Most weeks & 14 & 17 \\
\hline & \multirow{3}{*}{ Longer-Term } & Everyday & 1 & 14 \\
\hline & & Every week & 0 & 8 \\
\hline & & Most weeks & 3 & 5 \\
\hline
\end{tabular}


TABLE 4 Results of hierarchical log-linear analysis of the effects of gender, duration of bullying, frequency of bullying and perceived control: Tests of partial association

\begin{tabular}{|c|c|c|c|c|}
\hline Effect & df & G2 a & $\mathbf{p}$ & Iteration \\
\hline GENDER*DURATION*CONTROL & 1 & .06 & .80 & 3 \\
\hline GENDER*DURATION*FREQUENCY & 2 & .08 & .96 & 3 \\
\hline GENDER*CONTROL*FREQUENCY & 2 & 6.46 & $.04 *$ & 3 \\
\hline DURATION*CONTROL*FREQUENCY & 2 & 1.07 & .59 & 3 \\
\hline GENDER*DURATION & 1 & 1.62 & .20 & 3 \\
\hline GENDER*CONTROL & 1 & 14.44 & $.01 * *$ & 3 \\
\hline DURATION*CONTROL & 1 & 14.77 & $.01 * *$ & 3 \\
\hline GENDER*FREQUENCY & 2 & .55 & .76 & 3 \\
\hline DURATION*FREQUENCY & 2 & 9.20 & $.01 * *$ & 3 \\
\hline CONTROL*FREQUENCY & 2 & .10 & .95 & 4 \\
\hline GENDER & 1 & .28 & .60 & 2 \\
\hline DURATION & 1 & 12.63 & $.01 * *$ & 2 \\
\hline CONTROL & 1 & 2.04 & .15 & 2 \\
\hline FREQUENCY & 2 & 19.82 & $.01 * *$ & 2 \\
\hline
\end{tabular}

a. G2 indicates the likelihood ratio, a measure of goodness of fit 
TABLE 5 Contingency table for gender, duration of bullying, frequency of bullying and perceived control

\begin{tabular}{|c|c|c|c|}
\hline \multirow{2}{*}{ Gender } & Type of Bullying & Control & No Control \\
\hline \multirow{3}{*}{ Male } & Verbal & 24 & 20 \\
\cline { 2 - 4 } & Indirect & 8 & 4 \\
\cline { 2 - 4 } & Direct & 7 & 11 \\
\hline \multirow{3}{*}{ Female } & Verbal & 7 & 29 \\
\cline { 2 - 4 } & Indirect & 8 & 15 \\
\cline { 2 - 4 } & Direct & 7 & 10 \\
\hline
\end{tabular}


TABLE 6 Results of hierarchical log-linear analysis of the effects of gender, type of bullying \& perceived control: Tests of partial association

\begin{tabular}{|l|c|c|c|c|}
\hline \multicolumn{1}{|c|}{ Effect } & df & G2 a & p & Iteration \\
\hline GENDER*TYPE & 2 & 5.43 & 0.07 & 2 \\
\hline GENDER*CONTROL & 1 & 9.97 & $0.01 * *$ & 2 \\
\hline TYPE*CONTROL & 2 & 1.60 & 0.45 & 2 \\
\hline GENDER & 1 & 0.03 & 0.87 & 2 \\
\hline TYPE & 2 & 25.27 & $0.01 * *$ & 2 \\
\hline CONTROL & 1 & 5.26 & $0.02 *$ & 2 \\
\hline
\end{tabular}

a. G2 indicates the likelihood ratio, a measure of goodness of fit 
